\title{
FLUORESCENCE DETECTION OF AMYLOID DEPOSITS IN HUMAN TISSUES USING HISTOCHEMICAL DYES
}

\author{
Guselnikova $\mathrm{W}^{1,2} \otimes$, Sufieva $\mathrm{DA}^{1}$, Tsyba $\mathrm{DL}^{1}$, Korzhevskii DE ${ }^{1}$
}

${ }^{1}$ Institute of Experimental Medicine, Saint Petersburg, Russia

2 Saint Petersburg State University, Saint Petersburg, Russia Recently, fluorescence microscopy becomes more available, presenting new opportunities to face several challenges of experimental biology and medicine. The
study was aimed to assess the effectiveness of fluorescence microscopy for the identification of amyloid deposits in human tissues. Post-mortem samples of the
myocardium $(n=12$ ) and cerebral cortex ( $n=8$ ) obtained from subjects of both sexes aged $60-98$ with verified amyloidosis were used as a material for the study.
The specimens were stained using 11 different histochemical dyes and subsequently analyzed by light and fluorescence microscopy. Qualitative and quantitative
analysis has shown that Thioflavin T is the most effective stain for fluorescence detection of $\beta$ - and transthyretin amyloid in human tissues. Congo red staining is
highly effective for the detection of transthyretin amyloidosis, however, it is ill-suited for the identification of $\beta$-amyloid plaques. It has been found that the ability of
Congo red to exhibit fluorescence when binding to amyloid fibrils can be used for verification of amyloid deposits instead of the traditional polarized light microscopy.
As has been first noted, methyl violet can selectively bind to $\beta$-amyloid with fluorescent complex formation. In addition, methyl violet treatment effectively reduces
the autofluorescent background in the nervous tissue. This makes methyl violet staining a promising diagnostic tool for Alzheimer's-type pathology.

Keywords: fluorescence microscopy, amyloid, amyloid plaques, histochemistry, congo red, thioflavin, methyl violet

Author contribution: Guselnikova W — literature analysis, study planning, staining specimens, analysis and interpretation of the results, manuscript draft writing; Sufieva DA — quantitative data analysis; Tsyba DL — quantitative data analysis; Korzhevskii DE — conceptual development, study planning, manuscript editing.

Compliance with ethical standards: the study was conducted in accordance with the requirements of the World Medical Association Declaration of Helsinki (2013) and approved by the Ethics Committee of the Institute of Experimental Medicine (protocol № 3/18 dated November 22, 2018).

$\triangle$ Correspondence should be addressed: Valeria V. Guselnikova

Acad. Pavlov, 12, Saint Petersburg, 197376; Guselnicova.Valeriia@yandex.ru

Received: 12.07.2021 Accepted: 25.07.2021 Published online: 31.07.2021

DOI: 10.24075/brsmu.2021.034

\section{ПРИМЕНЕНИЕ ГИСТОХИМИЧЕСКИХ КРАСИТЕЛЕЙ ДЛЯ ФЛУОРЕСЦЕНТНОГО ВЫЯВЛЕНИЯ АМИЛОИДНЫХ СКОПЛЕНИЙ В ТКАНЯХ ЧЕЛОВЕКА}

\author{
В. В. Гусельникова ${ }^{1,2}$, Д. А. Суфиева 1 , Д. Л. Цыба ${ }^{1}$, Д. Э. Коржевский \\ 1 Институт экспериментальной медицины, Санкт-Петербург, Россия \\ ${ }^{2}$ Санкт-Петербургский государственный университет, Санкт-Петербург, Россия
}

\begin{abstract}
В последнее время метод флуоресцентной микроскопии приобретает все большее распространение, открывая новые возможности для решения целого ряда задач экспериментальной биологии и медицины. Целью настоящей работы было оценить эффективность применения метода флуоресцентной микроскопии для идентификации амилоидных скоплений в тканях человека. В качестве материала для исследования были использованы фрагменты миокарда $(n=12)$ и коры головного мозга $(n=8)$ людей обоих полов в возрасте от 60 до 98 лет с верифицированным амилоидозом. Препараты окрашивали с применением 11 разных гистохимических красителей с последующим анализом методами световой и флуоресцентной микроскопии. Проведенные качественный и количественный анализ показали, что тиофлавин Т является наиболее эффективным красителем для фрлуоресцентного выявления $\beta$ - и транстиретинового амилоида в тканях человека. Методика окраски конго красным обладает высокой эффективностью в отношении транстиретинового амилоидоза, но плохо подходит для идентификации $\beta$-амилоидных бляшек. Установлено, что способность конго красного флуоресцировать при связывании с амилоидными фибриллами может быть использована для верификации амилоидных скоплений вместо традиционной поляризационной микроскопии. Впервые отмечено, что краситель метиловый фиолетовый обладает способностью специфично связываться с $\beta$-амилоидными скоплениями с формированием флуоресцирующего комплекса, одновременно подавляя автофлуоресценцию нервной ткани. Это делает методику окраски метиловым фиолетовым перспективной для диагностики патологии альцгеймеровского типа.
\end{abstract}

Ключевые слова: флуоресцентная микроскопия, амилоид, амилоидные бляшки, гистохимия, конго красный, тиофлавин, метиловый фиолетовый

Вклад авторов: В. В. Гусельникова - анализ литературы, планирование исследования, окраска препаратов, анализ и интерпретация результатов, подготовка черновика рукописи; Д. А. Суфиева — количественный анализ данных; Д. Л. Цыба — количественный анализ данных; Д. Э. Коржевский — разработка концепции, планирование исследования, редактирование рукописи.

Соблюдение этических стандартов: исследование проведено в соответствии с требованиями Хельсинской декларации Всемирной медицинской ассоциации (2013) и одобрено этическим комитетом ФГБНУ «ИЭМ» (протокол № 3/18 от 22 ноября 2018 г.).

$\bowtie$ Для корреспонденции: Валерия Владимировна Гусельникова ул. Акад. Павлова, д. 12, г. Санкт-Петербург, 197376; Guselnicova.Valeriia@yandex.ru

Статья получена: 12.07.2021 Статья принята к печати: 25.07.2021 Опубликована онлайн: 31.07.2021

DOI: $10.24075 /$ vrgmu.2021.034

In recent years, fluorescence microscopy is being increasingly used for morphological studies. This method becoming a research tool available together with rapid introduction of the method into clinical diagnostic practice provide new opportunities to face a number of challenges of experimental biology and medicine. Improving methods for morphological diagnosis of amyloidosis is one of those challenges.

Amyloidosis is a group of protein-conformational diseases characterized by extracellular deposition of pathological insoluble fibrillar proteins, amyloids, in organs and tissues [1]. Amyloidosis is a severe condition having high mortality rate. The most malignant forms of amyloidosis occur in individuals of working age. Accumulation of amyloid in various organs (heart, kidney, liver, lungs, gastrointestinal tract, etc.) results in impaired organ function and can cause cardiomyopathy, heart and kidney failure, hepatic vein thrombosis, etc. Accumulation of amyloid in brain is a histopathological sign of such neurodegenerative diseases, as Alzheimer's disease and Parkinson's disease [2-4]. 
Differential diagnosis of amyloidosis is difficult due to great diversity of clinical manifestations and lack of pathognomonic symptoms. To date, histological examination of tissue specimens with the use of Congo red stain, and subsequent investigation of specimens using light and polarized light microscopy remains the most reliable diagnosis method [5]. However, application of such an approach often results in false positive and/or false negative findings [6], which indicates imperfect nature of the existing methods. This explains the urgency of the problem of searching for new approaches to improving the quality of amyloidosis morphological diagnosis. The use of fluorescence microscopy can make a definite contribution to that objective. Currently, many clinical and diagnostic centers are equipped with fluorescence microscopes, allowing them to use fluorescent properties of some dyes for diagnosis, including for diagnosis of amyloidosis.

The study was aimed to assess the effectiveness of fluorescence microscopy for identification of amyloid deposits in human tissues.

\section{METHODS}

Samples of myocardium ( $n=12)$ and cerebral cortex $(n=8)$, obtained from patients of both sexes ( 4 men and 8 women, 3 men and 5 women respectively) aged 60-98 with amyloidosis detected by immunohistochemistry, were used as a material for the study. Inclusion criteria: immunopositive $\beta$-amyloid plaques in cerebral cortex and accumulation of aggregated transthyretin in myocardium. Exclusion criteria: marked postmortem autolytic changes in brain tissue or myocardium.

Rabbit OC polyclonal antibody (Anti-Amyloid Fibrils OC Antibody) against the conformational epitopes of amyloid fibrils (1:1000 dilution, catalogue number AB2286, Sigma-Aldrich; USA) and mouse monoclonal (clone TA5F4) antibody targeting aggregated transthyretin (1:600 dilution, catalogue number 848102, BioLegend; USA) were used to verify the presence of amyloid deposits.

Biomaterial was received from the archive of the Department of General and Special Morphology, Institute of Experimental Medicine. Samples were fixed in 10\% formalin and embedded in paraffin. Paraffin blocks were sectioned in order to obtain the slices 5, 7 and $14 \mu \mathrm{m}$ thick. Human cerebral cortex and myocardium specimens were stained using a number of histochemical stains in order to assess the potential of using histochemical dyes for fluorescence detection of amyloid (Table 1).

Specimen analysis and imaging were performed using Leica DM750 light microscope (Leica Microsystems; Germany) and Leica DM2500 fluorescence microscope (Leica Microsystems;

Table 1. List of dyes used
Germany), equipped with a set of fluorescence filters 340$560 \mathrm{~nm}$. The filter set included the following excitation filters: $\mathrm{BP}=340-380 \mathrm{~nm}$ (the first - "A"), BP=450-490 nm (the second "I3") and BP=515-560 nm (the third - "N2.1").

Amyloid plaques detected by various techniques were counted in serial sections of cerebral cortex of the same case. The plaques were counted by three different researchers under identical conditions using the objective lens with a magnification of $\times 40$. Since the distribution of amyloid plaques in the nervous tissue was very uneven, the plaques were counted across the entire area of the slice $\left(0.67 \mathrm{~cm}^{2}\right)$, and after that the number of plaques per $\mathrm{cm}^{2}$ was calculated. The number of amyloid plaques detected by immunofluorescence assay was used as a reference value. Mouse monoclonal (clone DE2B4) antibody against $\beta$-amyloid (1:200 dilution, catalogue number ab11132, Abcam; UK) was used for that purpose; biotin-conjugated Fab fragment from a donkey anti-mouse immunoglobulin (Jackson ImmunoResearch; USA) and Cy2-conjugated streptavidin (Jackson ImmunoResearch; USA) were used as secondary reagents.

Statistical analysis of the data obtained was performed using the GraphPad Prism 9 software (GraphPad Software Inc.; USA). The indicators were compared using the analysis of variance (ANOVA) with subsequent pairwise comparison of groups (Thioflavin T, Congo red, methyl violet) with the control (immunohistochemistry) using the Dunnett's post-hoc test. The differences were considered significant when $p<0.05$. The data were presented in the following format: mean \pm standard error of the mean.

\section{RESULTS}

\section{Analysis of histochemical dye effectiveness for fluorescence detection of amyloid deposits}

The results of using various histochemical dyes for identification of $\beta$-amyloid and transthyretin amyloid by light and fluorescence microscopy are presented in Tables 2 and 3 respectively.

Three dyes are capable of binding to amyloid fibrils to form fluorescent complexes: Thioflavin $\mathrm{T}(\mathrm{ThT})$, Congo red and methyl violet.

When stained with ThT, amyloid plaques in cerebral cortex are clearly visible even at low magnification $(\times 10)$ of a microscope. The deposits detected look like compact focal lesions fluorescent in the blue range (Fig. 1A). Amyloid plaques are characterized by morphological heterogeneity: some plaques have a roundish intensely fluorescent dense central core surrounded by a fibrillar peripheral halo (Fig. 1A; arrow 1), while

\begin{tabular}{|c|c|c|}
\hline Dye & Manufacturer and producer country & Staining dye solution \\
\hline Congo red & Sigma, USA & $0.1 \%$ aqueous solution \\
\hline Thioflavin T & Fluka, USA & Commercially available solution \\
\hline Alcian blue & Acros Organics, USA & $1 \%$ alcohol solution \\
\hline Toluidine blue & Pr. G. Grubler, Germany & $0.1 \%$ aqueous solution \\
\hline Methyl violet & Ferak Berlin, Germany & $0.1 \%$ aqueous solution \\
\hline Methylene green & BioVitrum, Russia & Commercially available solution \\
\hline Eosin Y solution, alcoholic & Merck, Germany & $0.1 \%$ aqueous solution \\
\hline Janus green & British Drug Houses, UK & $0.1 \%$ aqueous solution \\
\hline Pyronin G & Serva, Germany & $0.1 \%$ aqueous solution \\
\hline Basic fuchsin & National Aniline Division, USA & $0.1 \%$ aqueous solution \\
\hline Neutral red & &
\end{tabular}


Table 2. Results of $\beta$-amyloid staining in human cerebral cortex

\begin{tabular}{|c|c|c|}
\hline Dye & $\begin{array}{c}\text { Color of amyloid deposits when viewed in } \\
\text { transmitted light }\end{array}$ & Fluorescence of amyloid deposits \\
\hline Congo red & Salmon pink & + \\
\hline Thioflavin T & - & - \\
\hline Alcian blue & Blue & - \\
\hline Toluidine blue & - & + \\
\hline Methyl violet & - & - \\
\hline Methylene green & - & - \\
\hline Eosin Y & Light pink & - \\
\hline Janus green & - & \\
\hline Pyronin G & - & \\
\hline Basic fuchsin & - & \\
\hline Neutral red & - & - \\
\hline
\end{tabular}

other plaques look like deposits formed of nothing but fibrillar structures (Fig. 1A; arrow 2). Fluorescence is characteristic of amyloid plaques of both types. When stained with ThT, these are visualized with uniform effectiveness (Fig. 1A). Analysis of specimens revealed low background fluorescence of cell nuclei and autofluorescent lipofuscin (pigment accumulated in neurons during aging).

When stained with ThT, transthyretin amyloid in human myocardium is also characterized by intense fluorescence in the blue range (Fig. 1B). Similarly to the cerebral cortex specimens assessment, background fluorescence of cell nuclei (Fig. 1B; arrow head, turquise) was observed in myocardium together with autofluorescence of lipofuscin granules (Fig. 1B, short arrow, orange), the accumulation of which is characteristic both of neurons and cardiomyocytes. It is important to highlight the following: despite the fact that the color of fluorescence in non-amyloid tissue component differs from the color of fluorescence in amyloid fibrils bound to ThT, the presence of additional fluorescent elements complicates identification and quantification of amyloid deposits.

Analysis of specimens stained with Congo red using fluorescence microscope showed that congophilic amyloid deposits in human tissues were fluorescent in the red range (Fig. 1C; 1D). When examining cerebral cortex specimens, it was noted that after staining with Congo red amyloid plaques were detected not in every studied specimen. Few congophilic deposits in brain tissue were identified only in three cases out of eight cases under investigation. When stained with Congo red, maximum fluorescence intensity was observed in the dense central core of amyloid plaque. Fibrillar peripheral halo was

Table 3. Results of transthyretin amyloid staining in human myocardium poorly visualized. Plaques with no compact core were poorly distinguishable compared to plaques with intensely fluorescent central area. Significant background fluorescence (in the red range) was also noted in the cell nuclei of cerebral cortex cells, red blood cells and lipofuscin (Fig. 1C).

When examining myocardium specimens stained with Congo red, amyloid deposits looked like fibrillar aggregates of varying size, located in the myocardial interstitial space, and intensely fluorescent in the red range (Fig. 1D). Lipofuscin autofluorescence was observed, which made it difficult to identify amyloid deposits, especially in case of accumulation of a large amount of this pigment by cardiomyocytes.

Analysis of specimens stained with methyl violet using fluorescence microscope showed that in that case amyloid plaques were intensely fluorescent in the blue range (Fig. 1E). Moreover, tissue background fluorescence was totally absent. Only weak dark crimson staining of nervous tissue was observed, which enhanced the contrast of the detected amyloid plaques (Fig. 1E). Total lack of background fluorescence significantly simplified identification of amyloid plaques. The plaques with or without the dense central core were visualized with equal effectiveness. It should be noted that transthyretin amyloid in human myocardium was not fluorescent when stained with methyl violet (in contrast to amyloid plaques in cerebral cortex), although when the stained specimens were viewed in transmitted light, amyloid deposits in myocardium were clearly visible due to metachromatic (deep purple) staining (Fig. 2A).

Staining of transthyretin amyloid with basic fuchsin was an interesting object found during the study. After application of this dye amyloid deposits become deep read when viewed in

\begin{tabular}{|c|c|c|}
\hline Dye & $\begin{array}{c}\text { Color of amyloid deposits when viewed in } \\
\text { transmitted light }\end{array}$ & Fluorescence of amyloid deposits \\
\hline Congo red & Salmon pink & + \\
\hline Thioflavin T & - & - \\
\hline Alcian blue & Blue & - \\
\hline Toluidine blue & Light purple & - \\
\hline Methyl violet & Deep purple & - \\
\hline Methylene green & - & - \\
\hline Eosin Y & Light pink & - \\
\hline Janus green & Grayish purple & - \\
\hline Pyronin G & Light pink & \\
\hline Basic fuchsin & Red & \\
\hline Neutral red & Dark red & - \\
\hline
\end{tabular}



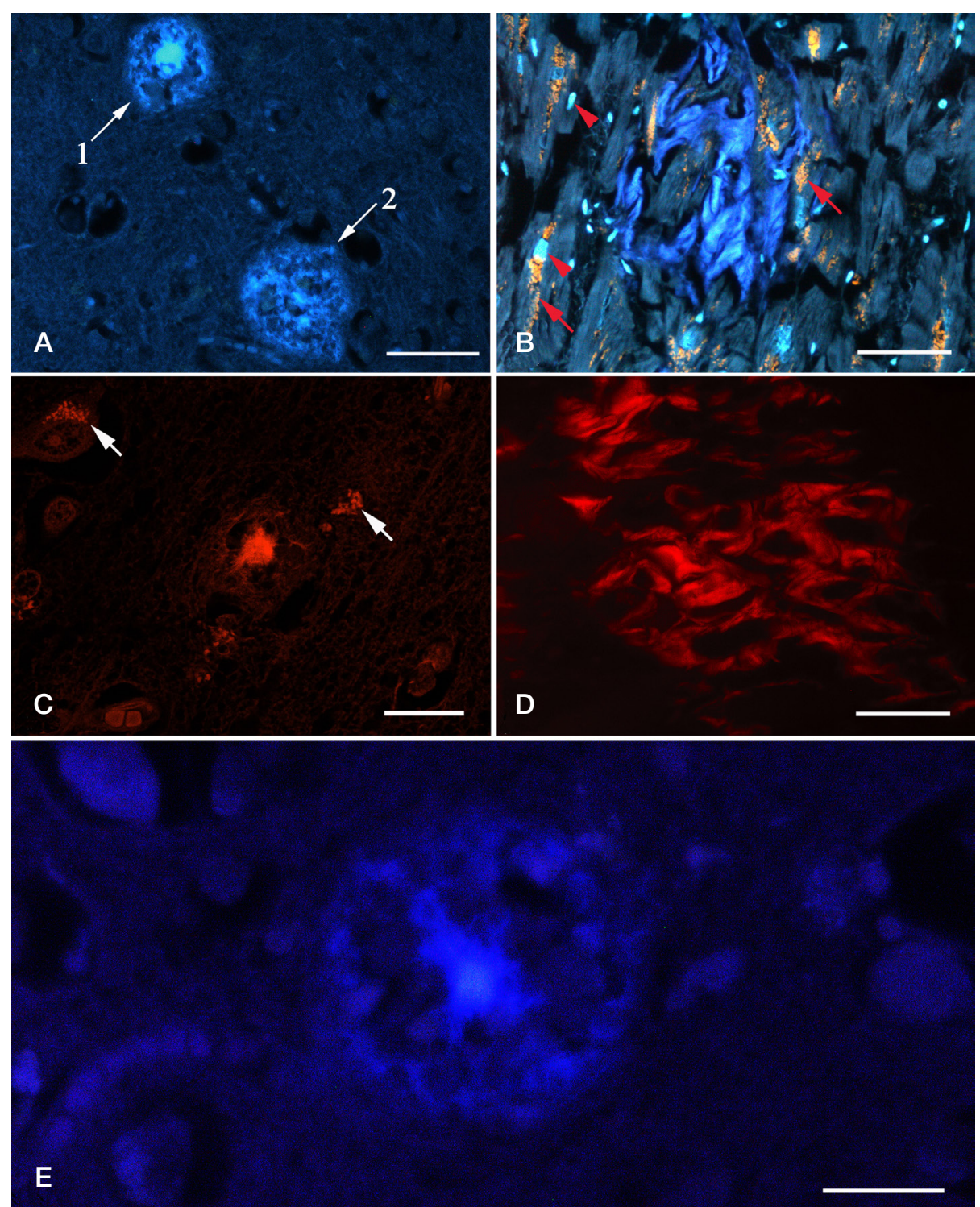

Fig. 1. Fluorescence detection of amyloid deposits in human cerebral cortex (A, C, E) and myocardium (B, D). Thioflavin T (A, B), Congo red (C, D) and methyl violet (E) staining. Arrow 1 points at amyloid plaque with dense central core, arrow 2 points at fibrillar amyloid plaque (no dense core), short arrow points at lipofuscin deposits, and the arrow head points at cell nucleus. The scale bar shows $50 \mu \mathrm{m}(\mathbf{A}, \mathbf{B}, \mathbf{D})$ and $20 \mu \mathrm{m}(\mathbf{C}, \mathbf{E})$

transmitted light (Fig. 2B). According to our data, metachromatic properties of basic fuchsin when staining amyloid have not been described earlier.

\section{Quantitative analysis of amyloid plaques detected using various dyes}

During analysis of human cerebral cortex specimens, it was noted that the visually detected number of amyloid plaques varied greatly depending on staining method. Therefore, the quantitative study was performed, which included counting of amyloid plaques in the specimens of the same case stained with different dyes by three different researchers. The quantitative analysis results are presented in Fig. 3. The results obtained were compared with the results of immunohistochemical assay for detecting $\beta$-amyloid fibrils, being the most sensitive method for amyloid plaque identification.

As shown in the histogram, the number of amyloid plaques detected using any histochemical dye is significantly lower than the number of immunopositive plaques. The average number of amyloid plaques detected by immunofluorescence staining in the sample, collected for quantitative analysis, was
$1106 \pm 76.72$ per $\mathrm{cm}^{2}$ of brain tissue. The minimum quantitative differences with the control group were observed when the slices were stained with ThT. After application of this stain the average number of amyloid plaques was $810.9 \pm 44.49$ per $\mathrm{cm}^{2}$. Maximum differences with the control group were observed when the slices were stained with Congo red: the number of visualized plaques was $268.1 \pm 15.34$ per $\mathrm{cm}^{2}$. The average number of amyloid plaques when stained with methyl violet was $399.0 \pm 60.03$ per $\mathrm{cm}^{2}$, which was the intermediate value between the results obtained for ThT and Congo red staining.

\section{DISCUSSION}

The ability to form fluorescent complexes when binding to cellular and tissue structures has been previously reported for a wide range of histochemical dyes. Thus, fluorescent properties of eosin are used for visualization of elastic fibers [7], liver injury assessment [8], spleen morphology evaluation [9], as well as for assessment of periodontal structure and function [10]. Basic fuchsin also demonstrates fluorescent properties when binding to elastic fibers [11]. Therefore, the search for new 
amyloid fibril-specific fluorescent probes among the known histochemical dyes may contribute to development of new approaches to the diagnosis of amyloidosis.

Staining of slices with ThT is the most well-known technique of amyloid fluorescence detection. It has been shown that molecules of this dye are able to specifically integrate into the $\beta$-sheet structure of amyloid fibrils. According to researchers, such integration blocks the rotation of the dimethylaminobenzene ring relative to the benzothiazole ring in the dye molecule, which leads to a significant (by thousand times) increase in fluorescence quantum yield [12].

According to literature, upon binding to amyloid fibrils, ThT demonstrates a dramatic shift of the excitation maximum from $385 \mathrm{~nm}$ to $450 \mathrm{~nm}$ and the emission maximum from $445 \mathrm{~nm}$ to $482 \mathrm{~nm}$ [13]. Therefore, it is common practice to assess fluorescence of ThT-stained amyloid deposits in the green range (with the use of excitation filter "I3" $B P=450-490 \mathrm{~nm}$ ). Our studies indicate that staining with ThT is an effective method of $\beta$ - and transthyretin amyloidosis visualization in human tissues. It is interesting that after ThT staining of human cerebral cortex and myocardium slices the intense amyloid fluorescence was observed not only in green, but also in blue range (with the use of excitation filter $\mathrm{BP}=340-380 \mathrm{~nm}$ ). Moreover, in this case the color of nervous and muscle tissue autofluorescent elements (lipofuscin, accumulating in neurons and cardiomyocytes during aging, NADPH, contained in mitochondria, etc.) was different from the color of ThT-stained amyloid fluorescence. This significantly enhances the contrast when detecting amyloid.

Despite the fact that ThT can selectively interact with proteins in the state of amyloid fibrils to form the intensely fluorescent complex, it is much less frequently used for clinical diagnosis than the other dye with similar mechanism of action, Congo red. Currently, Congo red stain is the gold standard for detection of amyloid. It is widely used in scientific research and clinical diagnostic practice $[14,5]$. Like ThT, Congo red integrates into $\beta$-sheet structure of amyloid fibrils acquiring the ability to rotate the plane of light polarization. Therefore, polarized light microscopy is a traditional method used to verify the type of congophilic deposits detected [14]. However, the color of fluorescence in congophilic deposits viewed under polarized light may vary greatly, which makes interpretation of the results obtained increasingly complicated [15].

We have shown that it can be recommended to use fluorescence microscopy instead of polarized light microscopy for verification of amyloid deposits after staining with Congo red. The ability of Congo red to exhibit fluorescence when binding to amyloid fibrils was reported back in 1959 [16]. However, the use of Congo red fluorescent properties was not widely implemented at the time. It was probably due to the fact that fluorescence microscopes were available only to a few diagnostic laboratories upon the time of the abovementioned article release. The use of Congo red ability to exhibit fluorescence when binding to amyloid may help to reduce the number of false positive and false negative findings, resulting from erroneous interpretation of the results due to variability of green hue of congophilic deposits fluorescence in polarized light. It is important to emphasize however that, according to our studies, staining with Congo red is ineffective for detection of $\beta$-amyloid plaques. This is evidenced by the fact that, when using Congo red, amyloid can be identified not in every specimen of cerebral cortex, containing $\beta$-amyloid plaques (based on immunohistochemical assay data). Moreover, the number of congophilic plaques in the specimen, selected for quantitative analysis, is four times lower than the value obtained after immunohistochemical staining.
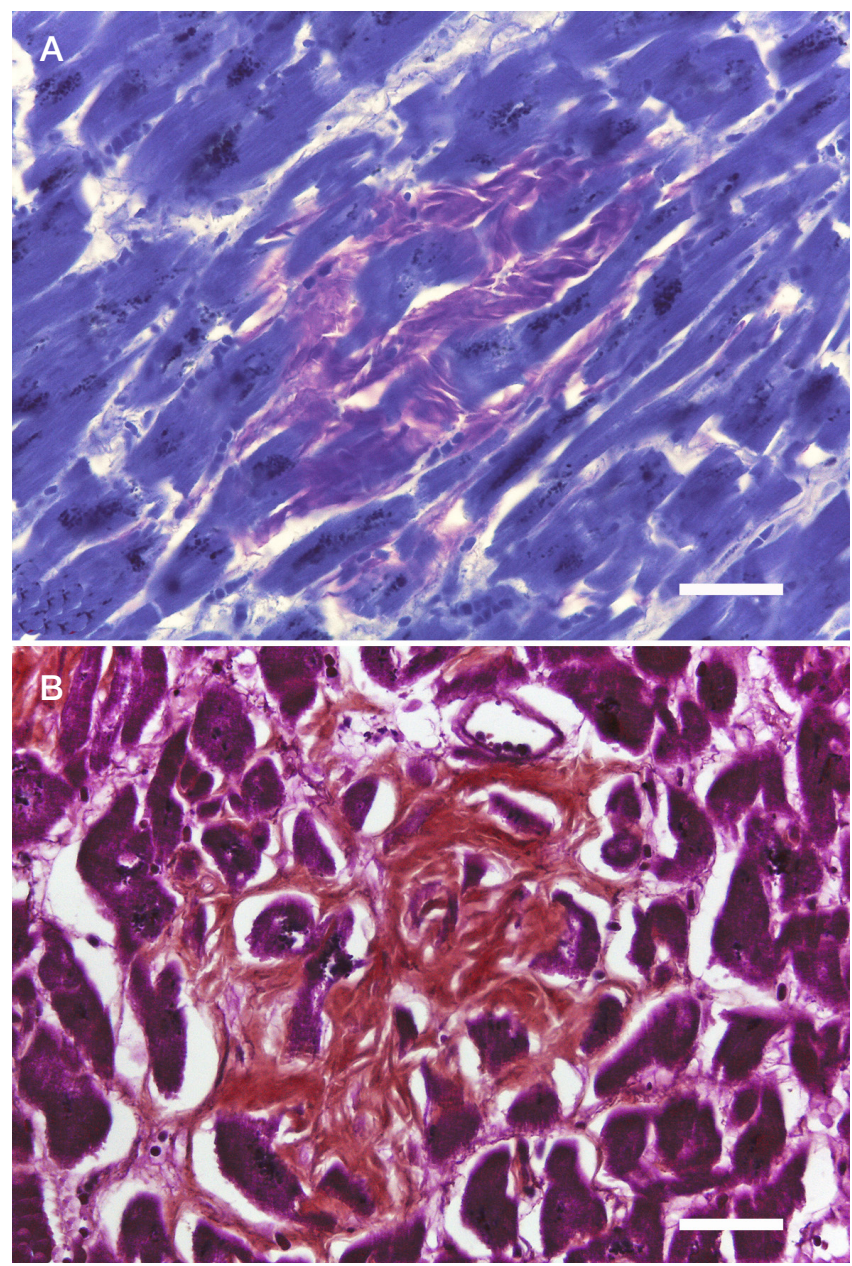

Fig. 2. Metachromatic staining of transthyretin amyloid in human myocardium. A. Methyl violet stain. B. Basic fuchsin stain. The scale bar shows $50 \mu \mathrm{m}$

The first attempts to detect amyloid using metachromatic dyes, such as toluidine blue, crystal violet, and methyl violet, began at the end of the last century. According to the studies of those years, these methods were significantly less effective in amyloid detection compared to staining with Congo red and ThT [17]. It should be noted that the assessment of specimens stained with metachromatic dyes has been earlier performed only by transmitted light microscopy. We have found that staining with methyl violet with subsequent verification of amyloid by fluorescence microscopy is an effective method for detection of $\beta$-amyloid plaques. In this case, it is much easier to identify amyloid plaques within the slice due to totally abscent backgroung fluorescence of non-amyloid tissue components. It has been previously shown that applying crystal violet, having the chemical structure similar to methyl violet, to paraffin tissue sections results in significantly reduced autofluorescence [18]. Methyl violet probably possesses similar properties. It is interesting that this staining method is ineffective for transthyretin myocardial amyloidosis. In this case amyloid demonstrates metachromasia when viewed in transmitted light. However, it is characterized by total abscence of fluorescence. This may indicate specific nature of methyl violet molecule binding to amyloid fibrils of certain type.

Identification of amyloid plaques in human cerebral cortex is an urgent challenge, since the presence of amyloid plaques is considered one of the main histological signs of Alzheimer's disease. During our studies, we have found that histochemical dyes analyzed interact with amyloid plaques to form fluorescent complexes with varying degrees of effectiveness. The observed 
differences in the number of amyloid plaques detected using different methods may be due to varying specificity of binding to $\beta$-amyloid fibrils shown by the dyes. Significant differences from immunofluorescence assays suggest that the histochemical dyes used don't bind to all amyloid plaques in the tissue, but only to some of them. This may be due to structural differences between different types of amyloid plaques. Thus, it has been found that diffuse (immature) amyloid plaques do not have fibrillar structure. Such plaques are the compact deposits of $\beta$-amyloid peptide [19]. Due to lack of amylois fibrils, these plaques are unable to interact with such dyes, as Congo red and ThT, the molecules of which are incorporated into structures with certain conformation. From this perspective, histochemical methods of amyloid detection are not entirely analogous to immunohistochemical methods, since the use of antibodies makes it possible to define where certain protein ( $\beta$-amyloid, transthyretin, etc.) is located. In this case histochemical methods are a more effective way of detecting conformational pathology.

In spite of the fact that quantitative data indicate lower effectiveness of using any histochemical stain for detection of amyloid plaques compared to immunofluorescence method, the results obtained could be of interest for future research. Immunofluorescence method is complicated and expensive due to high cost of reagents and disposables required. As a result, it can be used as a routine method in a minority of scientific, clinical diagnostics and pathomorphological laboratories. In contrast, histochemical methods are simple and cost-effective, being more widely available. The problem of these methods' lower effectiveness for amyloid detection can be partly solved by modifying the existing histochemical dyes and developing the analoques of those $[12,20]$.

\section{CONCLUSIONS}

The use of fluorescence microscopy gives rise to new approaches to visualization of amyloid in human tissues,

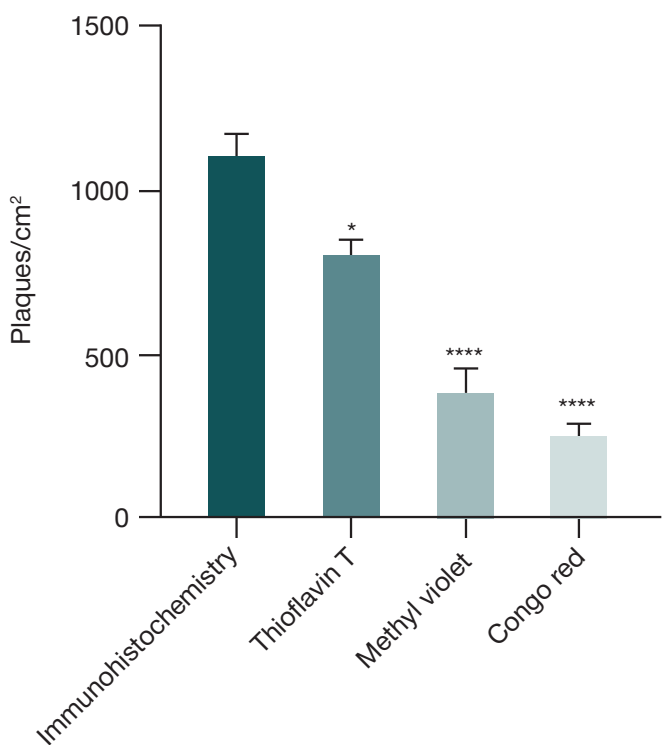

Fig. 3. Quantitative assessment of amyloid plaques stained using various methods. The differences with the control group (immunohistochemistry) are considered significant when $p=0.01\left(^{*}\right)$ and $p<0.0001^{(* \star *)}$

which can be successfully used to improve the effectiveness of amyloidosis morphological diagnosis. Thioflavin $T$ is the most effective histochemical dye for fluorescence detection of $\beta$ - and transthyretin amyloidosis in human tissues. Congo red staining method is highly effective for detection of transthyretin amyloidosis. However, it is ill-suited for identification of $\beta$-amyloid plaques. The ability of Congo red to exhibit fluorescence when binding to amyloid fibrils may be used for verification of amyloid deposits instead of polarized light microscopy. Methyl violet is able to specifically bind to $\beta$-amyloid deposits with fluorescent complex formation, simultaneously suppressing autofluorescence in nervous tissue. This makes methyl violet staining a promising method for the Alzheimer's-type pathology diagnosis.

\section{References}

1. Picken MM. The pathology of amyloidosis in classification: A review. Acta Haematol. 2020; 143 (4): 322-34. DOI: 10.1159/000506696.

2. Cuddy SAM, Falk RH. Amyloidosis as a systemic disease in context. Can J Cardiol. 2020; 36 (3): 396-407. DOI: 10.1016/j. cjca.2019.12.033.

3. DeTure MA, Dickson DW. The neuropathological diagnosis of Alzheimer's disease. Mol Neurodegener. 2019; 14 (1): 32. DOl: 10.1186/s13024-019-0333-5

4. Dickson DW. Neuropathology of Parkinson disease. Parkinsonism Relat Disord. 2017; 46 (Suppl 1): S30-S33. DOI: 10.1016/j. parkreldis.2017.07.033.

5. Dapson RW. Amyloid from a histochemical perspective. A review of the structure, properties and types of amyloid, and a proposed staining mechanism for Congo red staining. Biotech Histochem. 2018; 93 (8): 543-56. DOI: 10.1080/10520295.2018.1528385.

6. Yakupova El, Bobyleva LG, Vikhlyantsev IM, Bobylev AG. Congo Red and amyloids: history and relationship. Bioscience Reports. 2019; 39 (1): BSR20181415. DOI: 10.1042/BSR20181415

7. De Carvalho HF, Taboga SR. The applicability of hematoxylin-eosin staining plus fluorescence or confocal laser scanning microscopy to the study of collagen fibers in cartilages. Coll R Acad Sci III. 1996; 319: 991-6. PMID: 9064122.

8. Hamid A, Safdar A, Maryam M, Amjad A, Azra J, Abid A. Eosin fluorescence: A diagnostic tool for quantification of liver injury. Photodiagnosis Photodyn Ther. 2017; 19: 37-44. DOI: 10.1016/j. pdpdt.2017.03.016

9. Jakubovsky J, Guller L, Cerna M et al. Fluorescence of hematoxylin and eosin-stained histological sections of the human spleen. Acta Histochem. 2002; 104 (4): 353-6. DOI: 10.1078/0065-1281-00684.

10. De Rossi A, Rocha LB., Rossi MA. Application of fluorescence microscopy on hematoxylin and eosin-stained sections of healthy and diseased teeth and supporting structures. J Oral Pathol Med. 2007; 36 (6): 377-81. DOI: 10.1111/j.1600-0714.2007.00542.x.

11. Pihlman K, Linder $\mathrm{E}$. Fluorescence microscopical visualization of elastic fibres using basic fuchsin. Histochemistry. 1983; 79 (2):157-65. DOI: 10.1007/BF00489778.

12. Sapozhnikov SP, Karyshev PB, Sheptukhina Al, Nikolayeva OV, Avruyskaya AA, Mitrasov YN, Kozlov VA. Novel fluorescent probes for amyloid detection. CTM. 2017; 9 (2): 91-8. DOI: 10.17691/ stm2017.9.2.11.

13. Biancalana M, Koide S. Molecular mechanism of Thioflavin-T binding to amyloid fibrils. Biochim Biophys Acta. 2010; 1804 (7): 1405-12. DOI: 10.1016/j.bbapap.2010.04.001

14. Sipe JD, Benson MD, Buxbaum JN., Ikeda S-I, Merlini G, Saraiva MJM, Westermark P. Amyloid fibril proteins and amyloidosis: chemical identification and clinical classification International Society of Amyloidosis 2016 Nomenclature Guidelines. Amyloid. 2016; 23 (4): 209-13. DOl: 10.1080/13506129.2016.1257986.

15. Howie AJ, Mared P O-C. 'Apple-green birefringence' of amyloid stained by Congo red. Kidney Int. 2012; 82 (1): 114. DOI: 10.1038/ki.2012.89.

16. Cohen AS, Calkins E, Levene Cl. Studies on experimental amyloidosis. Analysis of histology and staining reactions of 
casein-induced amyloidosis in the rabbit. Am J Pathol. 1959; 35: 971-89. PMID: 13810917.

17. Elghetany MT, Saleem A. Methods for staining amyloid in tissues: a review. Stain Technol. 1988; 63 (4): 201-12. DOI: 10.3109/10520298809107185.

18. Buchynska L, Kashuba E, Szekely L. Immunofluorescence staining of paraffin sections: creating DAB staining like virtual digital images using CMYK color conversion. Exp Oncol. 2008;

\section{Литература}

1. Picken MM. The pathology of amyloidosis in classification: A review. Acta Haematol. 2020; 143 (4): 322-34. DOI: 10.1159/000506696.

2. Cuddy SAM, Falk RH. Amyloidosis as a systemic disease in context. Can J Cardiol. 2020; 36 (3): 396-407. DOI: 10.1016/j. cjca.2019.12.033.

3. DeTure MA, Dickson DW. The neuropathological diagnosis of Alzheimer's disease. Mol Neurodegener. 2019; 14 (1): 32. DOI: 10.1186/s13024-019-0333-5.

4. Dickson DW. Neuropathology of Parkinson disease. Parkinsonism Relat Disord. 2017; 46 (Suppl 1): S30-S33. DOI: 10.1016/j. parkreldis.2017.07.033.

5. Dapson RW. Amyloid from a histochemical perspective. A review of the structure, properties and types of amyloid, and a proposed staining mechanism for Congo red staining. Biotech Histochem. 2018; 93 (8): 543-56. DOI: 10.1080/10520295.2018.1528385.

6. Yakupova El, Bobyleva LG, Vikhlyantsev IM, Bobylev AG. Congo Red and amyloids: history and relationship. Bioscience Reports. 2019; 39 (1): BSR20181415. DOI: 10.1042/BSR20181415.

7. De Carvalho HF, Taboga SR. The applicability of hematoxylin-eosin staining plus fluorescence or confocal laser scanning microscopy to the study of collagen fibers in cartilages. Coll R Acad Sci III. 1996; 319: 991-6. PMID: 9064122.

8. Hamid A, Safdar A, Maryam M, Amjad A, Azra J, Abid A. Eosin fluorescence: A diagnostic tool for quantification of liver injury. Photodiagnosis Photodyn Ther. 2017; 19: 37-44. DOI: 10.1016/j. pdpdt.2017.03.016.

9. Jakubovsky J, Guller L, Cerna M et al. Fluorescence of hematoxylin and eosin-stained histological sections of the human spleen. Acta Histochem. 2002; 104 (4): 353-6. DOI: 10.1078/0065-1281-00684.

10. De Rossi A, Rocha LB., Rossi MA. Application of fluorescence microscopy on hematoxylin and eosin-stained sections of healthy and diseased teeth and supporting structures. J Oral Pathol Med. 2007; 36 (6): 377-81. DOI: 10.1111/j.1600-0714.2007.00542.x.

11. Pihlman K, Linder E. Fluorescence microscopical visualization
30 (4): 327-9. PMID: 19112433

19. Mott RT, Hulette CM. Neuropathology of Alzheimer's disease. Neuroimaging Clin N Am. 2005; 15: 755-65. DOI: 10.1016/j. nic.2005.09.003.

20. Styren SD, Hamilton RL, Styren GC, Klunk WE. X-34, a fluorescent derivative of Congo red: a novel histochemical stain for Alzheimer's disease pathology. J Histochem Cytochem. 2000; 48 (9): 1223-32. DOI: 10.1177/002215540004800906.

of elastic fibres using basic fuchsin. Histochemistry. 1983; 79 (2):157-65. DOI: 10.1007/BF00489778.

12. Sapozhnikov SP, Karyshev PB, Sheptukhina Al, Nikolayeva OV, Avruyskaya AA, Mitrasov YN, Kozlov VA. Novel fluorescent probes for amyloid detection. CTM. 2017; 9 (2): 91-8. DOI: 10.17691/ stm2017.9.2.11.

13. Biancalana M, Koide S. Molecular mechanism of Thioflavin-T binding to amyloid fibrils. Biochim Biophys Acta. 2010; 1804 (7): 1405-12. DOI: 10.1016/j.bbapap.2010.04.001.

14. Sipe JD, Benson MD, Buxbaum JN., Ikeda S-I, Merlini G, Saraiva MJM, Westermark P. Amyloid fibril proteins and amyloidosis: chemical identification and clinical classification International Society of Amyloidosis 2016 Nomenclature Guidelines. Amyloid. 2016; 23 (4): 209-13. DOI: 10.1080/13506129.2016.1257986.

15. Howie AJ, Mared P O-C. 'Apple-green birefringence' of amyloid stained by Congo red. Kidney Int. 2012; 82 (1): 114. DOI: 10.1038/ki.2012.89.

16. Cohen AS, Calkins E, Levene Cl. Studies on experimental amyloidosis. Analysis of histology and staining reactions of casein-induced amyloidosis in the rabbit. Am J Pathol. 1959; 35: 971-89. PMID: 13810917.

17. Elghetany MT, Saleem A. Methods for staining amyloid in tissues: a review. Stain Technol. 1988; 63 (4): 201-12. DOI: 10.3109/10520298809107185.

18. Buchynska L, Kashuba E, Szekely L. Immunofluorescence staining of paraffin sections: creating DAB staining like virtual digital images using CMYK color conversion. Exp Oncol. 2008; 30 (4): 327-9. PMID: 19112433.

19. Mott RT, Hulette CM. Neuropathology of Alzheimer's disease. Neuroimaging Clin N Am. 2005; 15: 755-65. DOI: 10.1016/j. nic.2005.09.003.

20. Styren SD, Hamilton RL, Styren GC, Klunk WE. X-34, a fluorescent derivative of Congo red: a novel histochemical stain for Alzheimer's disease pathology. J Histochem Cytochem. 2000; 48 (9): 1223-32. DOI: 10.1177/002215540004800906. 